\title{
Bone Marrow, Peripheral Blood, or Umbilical Cord Blood: Does the Source of Allogeneic Hematopoietic Progenitor Cells Matter?
}

\section{Rainer Seitz*, Anneliese Hilger and Margarethe Heiden}

Paul Ehrlich Institute, Division Hematology/Transfusion Medicine, Paul-Ehrlich-Str. 51-57, D-63225 Langen, Germany

\section{Introduction}

Rescue of the blood and immune cell production by transplantation of donor Hematopoietic Progenitor Cell (HPC) preparations has become an indispensable intervention for malignant and nonmalignant diseases. When a suitable donor is identified, currently two types of procedures may be employed to obtain progenitor cells. (i) Aspiration of 500 to maximal 1500ml Bone Marrow (BM) blood under general anesthesia from the iliac crest or (ii) harvest of progenitor cells by apheresis of mononuclear cells from peripheral blood (PB) after pretreatment with substances like Granulocyte-Colony Stimulating Factor (G-CSF) or a CXCR4 antagonist, which mobilize progenitor cells from bone marrow. The decision for one of the two procedures mainly depends on donor characteristics (e.g. condition of veins needed for access to apheresis or contraindications against anesthesia) and preferences of the donor and/or the transplant center. In recent years, as a third source of progenitor cells, blood from placenta and umbilical cord (cord blood, CB) has become available.

The legislation regulating the procurement and use of medicinal products of human origin has changed in the past decades. While for a long time blood products had been regarded as replacement of physiological substances, they became subject to the pharmaceutical legislation in the year 1989 under the impression of massive transmission of viruses such as HIV. Meanwhile, in Europe also a legal frame for blood components for transfusion has been established [1]. In Germany, providers of HPC preparations have to submit an application in order to obtain approval by the Paul-Ehrlich-Institute (PEI), which is a German higher competent authority responsible for blood products, clinical trial, marketing authorization and vigilance. Such applications comprise description of harvesting and manufacturing procedure, testing for safety, quality and functionality, supported by quality and non-clinical data (e.g. investigating excipients like cryo-preservatives) and clinical data supporting its use as bone marrow replacement. According to the European legislation [2], clinical trials have to be conducted following Good Clinical Practices. The sponsors of clinical studies have to submit applications to an independent ethics committee for review and to a competent regulatory authority, which for HPC is in Germany the PEI.A quality and non-clinical documentation needs to be provided with each clinical trial application.

One of the major problems in stem cell transplantation is to find a suitable cell preparation for each patient, since the donor cells need to be immunologically matched to the recipient, particularly to his HLA antigens [3]. Usually, closely related donors would be preferred, but in certain circumstances also haploidentical related or unrelated donors may be chosen [4].

In this paper, the three sources of $\mathrm{HPC}$, i.e. $\mathrm{BM}, \mathrm{PB}$ and $\mathrm{CB}$, are compared, with a particular focus on comparison of clinical outcomes. In addition, an anonymized overview will be presented of clinical trials with HPC which have been approved by the PEI in the years 2005 to 2010 , covering not only the transplantation for rescue of bone marrow function, but also applications in tissue regeneration.

\section{Comparison of BM, PB and CB Preparations}

The choice of the preparation for a given patient usually depends on the availability of a suitable donor. In many indications, HPC from either $\mathrm{BM}$ or $\mathrm{PB}$ can be used; if no such preparation is available, $\mathrm{CB}$ may alternatively be used. Since the therapy is complex and often under pressing time constraints due to the patient's deteriorating condition, all three types of HPC may be used more or less interchangeably according to their availability. An overview of some general aspects is provided in Table 1.

In contrast to e.g. stable plasma derivatives, where tight specifications can be set and batch release is performed by manufacturer and official control laboratories, each HPC preparation is a unique medicine. Nevertheless, the collection of HPC should follow accepted standards and the quality of HPC has to be assured by laboratory testing of their composition, including differential cell counts with particular focus on the determination of surface antigens such as CD34 [5]. Functional assays, such as determination of Colony Forming Units (CFU) are difficult to standardize. Different processing procedures may be necessary depending on e.g. minor (plasma reduction) or major (red blood cell reduction) ABO incompatibility, on HLA mismatch ( $\mathrm{T}$ cell depletion or $\mathrm{CD} 34+$ cell selection) or on storage duration requirements (cryo-preservation). Variations of measured quality parameters may be enhanced by different preparation steps. Moreover, there is a great individual variability of donors' bone marrow and blood and thereby the HPC collected from them. Therefore, specifications for HPC usually cover a broad range for key parameters such as volume, total nucleated cell and CD34+/CD45+ cell content.

HPC from $\mathrm{BM}, \mathrm{PB}$ and $\mathrm{CB}$ are quite different in many aspects. Nevertheless, our knowledge about a possible impact of type and composition of transplanted HPC on parameters of clinical outcome is still incomplete. Aretrospective study [6] of HPC transplantation for various (predominantly malignant) diseases compared cell composition of $181 \mathrm{~PB}$ and $94 \mathrm{BM}$ grafts and clinical outcomes. While within the $\mathrm{BM}$ group, parameters of cellular composition did not correlate with hematopoietic recovery, Graft-Versus-Host Disease (GVHD) or survival, in the $\mathrm{PB}$ group survival rates at 1 year were higher with a CD34+ cell dose $>5 \times 10^{6} / \mathrm{kg}$ body weight and patients' platelet count was higher with $\mathrm{PB}$ grafts containing $>8 \times 10^{7} \mathrm{CD} 3+\mathrm{CD} 8+\mathrm{T}$-cells /

${ }^{*}$ Corresponding author: Prof. Dr. Rainer Seitz, Paul Ehrlich Institute, Division Hematology/Transfusion Medicine, Paul-Ehrlich-Str. 51-57, D-63225 Langen, Germany, Tel: 496103 772600; Fax: +49 6103 771250; E-mail: Rainer.Seitz@pei.de

Received January 06, 2012; Accepted February 07, 2012; Published February 13,2012

Citation: Seitz R, Hilger A, Heiden M (2012) Bone Marrow, Peripheral Blood, or Umbilical Cord Blood: Does the Source of Allogeneic Hematopoietic Progenitor Cells Matter? J Blood Disord Transfus S1:007. doi:10.4172/2155-9864.S1-007

Copyright: (c) 2012 Seitz R, et al. This is an open-access article distributed under the terms of the Creative Commons Attribution License, which permits unrestricted use, distribution, and reproduction in any medium, provided the original author and source are credited. 


\begin{tabular}{|c|c|c|c|}
\hline & BM & PB & CB \\
\hline Mode of collection & $\begin{array}{l}\text { Usually in operation theatre, under gen- } \\
\text { eral anesthesia, puncture of spinailiaca } \\
\text { posterior, aspiration of up to } 20 \mathrm{ml} / \mathrm{kg} \text { body } \\
\text { weight BM containing blood (corresponding } \\
\text { to maximal } 1500 \mathrm{ml} \text { or } 25 \% \text { of blood volume } \\
\text { in children) anticoagulated with Citrate and } \\
\text { / or heparin }\end{array}$ & $\begin{array}{l}\text { Mobilization of progenitor cells from bone } \\
\text { marrow with eg; G-CSF pretreatment, } \\
\text { apheresis of mononuclear cells into } \\
\text { citrate anticoagulant }\end{array}$ & $\begin{array}{l}\text { After completed birth collection of blood } \\
\text { from umbilical cord into citrate antico- } \\
\text { agulant }\end{array}$ \\
\hline Typical processing steps & $\begin{array}{l}\text { Removal of larger particulate matter by } \\
\text { filtration, depending on } \mathrm{ABO} \text { compatibility } \\
\text { plasma or red cell reduction; Selection } \\
\text { and/or depletion of cells according to CD } \\
\text { markers }\end{array}$ & $\begin{array}{l}\text { If needed volume reduction; selection } \\
\text { and/or depletion of cells according to } C D \\
\text { markers }\end{array}$ & Depletion of red cells, volume reduction \\
\hline Storage & $\begin{array}{l}\text { Liquid storage after collection up to } 72 \mathrm{~h} \text { at } \\
2 \text { to } 6^{\circ} \mathrm{C} \text {, or up to } 48 \mathrm{~h} \text { at room temperature, } \\
\text { or freezing within } 72 \mathrm{~h} \text { after collection in a } \\
\text { suitable cryoprotectant (e.g. } 10 \% \text { DMSO): } \\
140^{\circ} \mathrm{C} \text { (above or in liquid nitrogen) several } \\
\text { years as validated }\end{array}$ & $\begin{array}{l}\text { Liquid storage after collection up to } 72 \mathrm{~h} \\
\text { at } 2 \text { to } 6^{\circ} \mathrm{C} \text {, or up to } 48 \mathrm{~h} \text { at room tem- } \\
\text { perature, or freezing within } 72 \mathrm{~h} \text { after col- } \\
\text { lection in a suitable cryoprotectant (e.g. } \\
10 \% \mathrm{DMSO} \text { ): } \leq 140^{\circ} \mathrm{C} \text { (above or in liquid } \\
\text { nitrogen) several years as validated }\end{array}$ & $\begin{array}{l}\text { Freezing within } 48 \mathrm{~h} \text { in a suitable cryo- } \\
\text { preservative solution (e.g. } 10 \% \text { DMSO): } \\
\leq 140^{\circ} \mathrm{C} \text { (above or in liquid nitrogen) } \\
\text { several years as validated }\end{array}$ \\
\hline Dose rate autologous & $\geq 2 \times 10^{8}$ nucleated cells/kg body weight & $\begin{array}{l}\geq 2 \times 10^{6} \mathrm{CD} 34^{+} \mathrm{CD} 45^{+} \text {cells } / \mathrm{kg} \text { body } \\
\text { weight }\end{array}$ & $\begin{array}{l}\geq 1.5 \times 10^{7} \text { nucleated or } \mathrm{CD} 45^{+} \text {cells } / \mathrm{kg} \\
\text { body weight }\end{array}$ \\
\hline Dose rate allogeneic & $\geq 2 \times 10^{8}$ nucleated cells/kg body weight & $\begin{array}{l}\geq 4 \times 10^{6} \mathrm{CD} 34^{+} \mathrm{CD} 45^{+} \text {cells } / \mathrm{kg} \text { body } \\
\text { weight }\end{array}$ & $\begin{array}{l}\geq 3 \times 10^{7} \text { nucleated or } \mathrm{CD} 45^{+} \text {cells } / \mathrm{kg} \\
\text { body weight }\end{array}$ \\
\hline
\end{tabular}

Table 1: Characteristics of HPC preparations for allogeneic transplantation in accordance with guidelines of the German Medical Association after consultation with the PEI

kg body weight. A study on HLA matched allogeneic transplantation for aplastic anemia [7] compared 225 patients receiving BM with 71 patients receiving $\mathrm{PB}$ grafts. Hematopoietic recovery was found to be similar, but grade 2 to 4 acute GVHD and mortality were higher in the $\mathrm{PB}$ group and the authors recommended $\mathrm{BM}$ as the preferred graft type. A comparison of 1,028 unrelated $\mathrm{BM}$ with $351 \mathrm{CB}$ transplantations with myeloablative conditioning for acute leukemia or myelodysplastic syndromes [8] showed similar overall mortality. CB showed inferior neutrophil recovery, but lower risk of acute GVHD, lower risk of transplant-related mortality and similar risk of relapse; the authors therefore consider $\mathrm{CB}$ a reasonable alternative.

For only about one third of patients HLA-identical family donors are available, therefore HPC transplantation from mismatched donors, e.g. from haploidentical related donors was introduced [9]. However, this approach implicates transgression of the HLA barrier, thus increasing the risk of GVHD. One approach to improve the outcome is reduction of graft T-cells, which appear to mediate GVHD. On the other hand, there is concern that T-cell depletion might result in prolonged immunodeficiency predisposing to serious infections and reduce the much desired anti-leukemia effect of HPC transplantation. There are protocols and commercial devices for depletion of CD3+ and $\mathrm{CD} 19+$, or positive selection of CD34+ or CD $133+$ cells. A randomized multicenter trial [10] compared CD34+ selected PB grafts with non-selected BM grafts, both from HLA identical sibling donors, for transplantation for hematological malignancies. PB grafts contained more CD3+ cells (despite selection) and more CD34+ cells; platelet and neutrophil recovery were faster, but grade 2 to 4 GVHD were higher with $\mathrm{PB}$, in relation to $\mathrm{CD} 3+$ cell dose. CD34+ cell dose was inversely correlated with treatment-related mortality, but the latter was higher in $\mathrm{PB}$ recipients. The 4 year survival was decreased in patients receiving $>2 \times 10^{5} \mathrm{CD} 3+$ cells / kg body weight and was significantly better in BM recipients. However, such results need to be interpreted with much caution. As an evaluation of the European Group for Blood and Bone Marrow Transplantation (EBMT) of results of haploidentical transplantation of children with acute lymphatic leukemia [11] showed, many variables influence the outcome of this very complex treatment, eg; disease stage and pretreatment, type of T-cell depletion, CD34+ cell dose, use of total body irradiation, immunosuppressive medication and interestingly the size (and thus experience) of the center.
In recent years, there are growing efforts to employ HPC in regenerative medicine applications, which are regulated under a special European Regulation for advanced therapy medicinal products [12]. Examples are the use of not substantially manipulated HPC preparations in cardiovascular indications (for review compare [13]) and in children with type 1 diabetes [14]. In these relatively new indications less than in "classical" HPC transplantation is known about the "active substance". This means that in many cases the cell type responsible for the desired effect is not entirely clear. Not only "hematopoietic" cells, but for instance also mesenchymal stem cells which can be found in BM and $\mathrm{CB}$ preparations appear to play a role in tissue repair [15]. In many new indications the mechanism of action, the significance of other cells contained in the preparation ("impurities") and the benefit risk ratio is not sufficiently elucidated. The situation is even more complex when HPC are used as starting material for novel medicines, e.g. in gene therapy or tissue engineering. Much more information is needed from non-clinical studies and clinical trials. There is only one aspect which reduces the obvious complexity: so far most of these approaches involve autologous cell preparations. Nevertheless, there are visions in the public domain to use e.g. $\mathrm{CB}$ as an indefinite source of tissue repair.

Hence, there are many open questions related to both therapeutic fields, in which HPC preparations are used, i.e. the "conventional" HPC transplantation for rescue of hematopoiesis and immune system and the development of advanced therapy medicinal products. In the years 2005 to 2010, a total of 22 clinical trials with HPC have been approved by the PEI (Table 2). For each study, the EudraCT number is listed; the sponsors of these studies and further details can be found in the EU Clinical Trials Register (https://www.clinicaltrialsregister.eu/). 15 of these trials explore the use of autologous HPC (in 10 studies BM, in 4 studies $\mathrm{PB}$ and in 1 study $\mathrm{CB}$ ). Two of the 15 studies address the use of autologous HPC for rescue of hematopoiesis after intensive therapy of malignancies (one study each in Ewing sarcoma and multiple myeloma) and one an autoimmune disease. In the other 12 trials with autologous HPC treatment of cardiovascular or metabolic diseases is studied. None of the studies on tissue repair uses allogeneic HPC; all 7 studies with allogeneic HPC address hematological malignancies. 3 of these trials involve CD3/CD19-depleted PB preparations. 
Citation: Seitz R, Hilger A, Heiden M (2012) Bone Marrow, Peripheral Blood, or Umbilical Cord Blood: Does the Source of Allogeneic Hematopoietic Progenitor Cells Matter? J Blood Disord Transfus S1:007. doi:10.4172/2155-9864.S1-007

Page 3 of 4

\begin{tabular}{|c|c|c|}
\hline EudraCT Number & Preparation & Short title, Indication \\
\hline \multicolumn{3}{|l|}{2005} \\
\hline $2005-000774-46$ & BM, autologous & BOOST-2, myocardial regeneration \\
\hline 2005-000968-33 & BM, autologous & PROVASA, chronic limb ischemia [27] \\
\hline 2005-000969-19 & BM, autologous & RENERVATE, diabetic neuropathy \\
\hline 2005-003629-19 & BM, autologous & Myocardial regeneration \\
\hline \multicolumn{3}{|l|}{2006} \\
\hline $2005-005709-50$ & BM, autologous & $\begin{array}{l}\text { CELLWAVE, Combined Extra corporal Shock Wave Therapy and Intracoronary Cell Therapy in } \\
\text { Chronic Ischemic Myocardium }\end{array}$ \\
\hline 2005-004051-35 & BM, autologous, CD133+ & INSTEM, myocardial regeneration, combined with Trans Myocardial Laser Revascularisation (TMLR) \\
\hline $2006-000393-76$ & PB, allogeneic, CD3/CD19 depleted & Hematological disorders in pediatric patients \\
\hline $2005-004028-38$ & BM, autologous, CD133+ & Chronic cardiac ischemia \\
\hline \multicolumn{3}{|l|}{2007} \\
\hline 2006-006404-11 & PB, autologous, CD133+ & $\begin{array}{l}\text { PERFECT, Intramyocardial transplantation for Improvement of Post-Infarct Myocardial Regeneration } \\
\text { in Addition to Surgery }\end{array}$ \\
\hline 2007-004874-14 & BM, autologous & REPAIR,Reinfusion of Enriched Progenitor cells And Infarct Remodeling in non-ST elevation AMI \\
\hline \multicolumn{3}{|l|}{2008} \\
\hline 2007-007694-23 & $\mathrm{CB}$, autologous & Umbilical cord blood to reverse DM type I in children \\
\hline $2006-001269-40$ & PB, autologous, CD34+ & Severe lupus erythematodes \\
\hline 2007-006016-33 & PB, allogeneic, CD3/CD19 depletion & Reduced conditioning in adult leukemia patients \\
\hline $2008-004625-42$ & BM, autologous & AMl; intramyocardial application \\
\hline 2007-003514-34 & PB, allogeneic & Comparing chemotherapy with stem cell transplantation in elderly with AML \\
\hline 2008-003658-13 & PB, autologous & EWING 2008; Ewing sarcoma, chemotherapy versus chemotherapy + HPC \\
\hline \multicolumn{3}{|l|}{2009} \\
\hline $2008-008368-28$ & BM, autologous & Ischemic cardiomyopathy, intramyocardial application \\
\hline $2007-004517-34$ & PB, allogeneic, CD3/CD19 depletion & Relapsed or refractory AML (including children) \\
\hline \multicolumn{3}{|l|}{2010} \\
\hline 2009-013856-61 & PB, autologous & multiple myeloma; combined with lenalidomid/dexamehtason \\
\hline $2010-019377-15$ & $\mathrm{BM}$ or $\mathrm{PB}$, allogeneic & AML; allogeneic HPC versus chemotherapy \\
\hline 2008-001669-27 & PB, allogeneic & Poor-risk CLL \\
\hline 2010-018467-42 & PB, allogeneic & MDS; 5-Azacytidine versus 5-Azacytidine + allogeneic HPC \\
\hline
\end{tabular}

AMI: Acute Myocardial Infarction; AML: Acute Myeloid Leukemia; CLL: Chronic Lymphatic Leukemia; DM: Diabetes mellitus; MDS: Myelo Dysplastic Syndrome.

Table 2: Clinical trials approved by the PEI in the years 2005 to 2010.

\section{Concluding Remarks}

The use of donor HPC for rescue of the blood and immune cell production is a well-established option for treatment of many malignant and non-malignant diseases. However, particularly studies on high intensity treatment of hematological malignancies focus predominantly on the definition of the most appropriate disease stage and response to pretreatment for inclusion of the patients, the modalities of chemo-/ radiotherapy often called "conditioning" of the patient, or supportive treatment such as immune suppression to reduce the GVHD risk. The HPC itself is often regarded as "ancillary" and BM, PB and in recent years also $\mathrm{CB}$ grafts are used more or less interchangeably. The choice of HPC-source for a given patient often depends on the availability of a suitable preparation.

Particularly for pediatric patients, $\mathrm{CB}$ grafts are increasingly accepted as an alternative to $\mathrm{BM}$ and $\mathrm{PB}$ in hematological malignancies [16] and metabolic disorders [17]. There are several advantages of $\mathrm{CB}$, e.g. the abundant availability and the collection without risk for mother and newborn. Moreover, $\mathrm{CB}$ grafts permit a higher degree of HLA disparity and lead to reduced incidence and severity of GVHD. However, there are apparently also some draw-backs such as delayed neutrophil and platelet engraftment [18] and increased risk of serious infections [19] which has been attributed to the naive state of CB T cells and more potent suppressor function of $\mathrm{CB}$ compared to adult regulatory $\mathrm{T}$ cells. A further important hurdle against the use of $\mathrm{CB}$ in adults is the limited volume and thus $\mathrm{CD} 34+$ cell dose of average $\mathrm{CB}$ preparations. Strategies to overcome this limitation are the concept of double-unit CB transplantation [20], or ex vivo expansion [21] which still needs further refinement. A practical issue is that $\mathrm{CB}$ is so far less cost effective compared to $\mathrm{BM}$ and $\mathrm{PB}$, mainly because a large number of $>500,000 \mathrm{CB}$ has been banked worldwide, but only about 3,800 CB have been transplanted up to 2009 [22]; still public funding for $\mathrm{CB}$ banks is needed.

Anyway, one would expect that the different origin of $\mathrm{BM}, \mathrm{PB}$ and $\mathrm{CB}$ and variations in cell composition and functionality should somehow translate into differential clinical effects and also safety profiles. It is understood that it is very difficult to elucidate such differences due to the highly individualized nature of the HPC preparations, diversity of disorders to be treated, influence of HPC processing steps, diversity of treatment modalities including co-medications and further confounding factors which even encompass the experience of the centers procuring and using the grafts.

It can even be expected that with further progress of experimental cognition and technology, more refined processing and thus further variations in the cellular composition of HPC will be introduced, which in turn will warrant advanced quality control methods. An example is the increasing use of new "mobilizing" agents such as plerixafor in addition to G-CSF, which leads to a higher content of more primitive progenitor cells in PB grafts [23]. Recent results suggest that genomic and proteomic analysis may become important, since mitotic quiescence and differential gene expression patterns appear to be significant for engraftment [24]. Further recent findings are that the 
genotype of Ig-like receptor on donor natural killer cells has impact on both immunity status and infections [25] and relapse-free survival after unrelated HPC transplantation for acute myeloid leukemia [26]. If the clinical significance of such new insights can be further substantiated, methods to process the grafts accordingly and to verify the consistent efficacy of these methods will become very important. This is even more applicable to HPC used in regenerative medicine for advanced therapy medicinal products such as tissue engineering or gene therapy products.

Notwithstanding the acknowledgement of the very high degree of complexity, it will be necessary to increase our knowledge by clinical studies on the respective contributions of the different cell types contained in therapeutic HPC to both clinical efficacy and potential risks. Such enhanced insight will be crucial for further developing and optimizing HPC as important medicines, defining "active substances" and impurities, advancing processing technology and improving quality control. In this situation, it will be particularly important to prioritize questions and to conduct sufficiently sized clinical trials in a concerted way in order to have a sufficient number of patients studied to obtain meaningful answers. It is understood that this can only be done in close collaboration of scientific networks and well-designed multicenter studies. In this setting, it will be important to take all possible steps to approximate as far as possible all variables from the collection and processing of grafts over the treatment modalities and co-medications up to assessment and evaluation of clinical endpoints. In this respect, the application of Good Clinical Practices should not only be seen as a further burden, but also an important and helpful quality standard for these much awaited clinical trials.

\section{References}

1. Seitz R, Heiden M, Nübling CM, Unger G, Löwer J (2008) The harmonization of the regulation of blood products: a European perspective. Vox Sang 94: 267-276.

2. Directive 2001/20/EC of the European Parliament and of the Council (2001) Approximation of the laws, regulations and administrative provisions of the Member States relating to the implementation of good clinical practice in the conduct of clinical trials on medicinal products for human use.

3. Lee SJ, Klein J, Haagenson M, Baxter-Lowe LA, Confer DL, et al. (2007) High-resolution donor-recipient HLA matching contributes to the success of unrelated donor marrow transplantation. Blood 110: 4576-4583.

4. Eapen M, Wagner JE (2010) Transplant Outcomes in Acute Leukemia (I) Semin Hematol 47: 46-50.

5. Salge-Bartels U, Huber HM, Kleiner K, Volkers P, Seitz R, Heiden M (2009) Evaluation of Quality Parameters for Cord Blood Donations. Transfus Med Hemother 36: 317-324.

6. Collins NH, Gee AP, Durett AG, Kan F, Zhang MJ, et al. (2010) The Effect of the Composition of Unrelated Donor Bone Marrow and Peripheral Blood Progenitor Cell Grafts on Transplantation Outcomes. Biol Blood Marrow Transplant 16: 253-262.

7. Eapen M, Le Rademacher J, Antin JH, Champlin RE, Carreras J, et al. (2011) Effect of stem cell source on outcomes after unrelated donor transplantation in severe aplastic anemia. Blood 118: 2618-2621.

8. Atsuta Y, Morishima Y, Suzuki R, Nagamura-Inoue T, Taniguchi S, et al. (2011) Comparison of Unrelated Cord Blood Transplantation and HLA-Mismatched Unrelated Bone Marrow Transplantation for Adults with Leukemia. Biol Blood Marrow Transplant [Epub ahead of print]

9. Symons HJ, Fuchs EJ (2008) Hematopoietic SCT from partially HLAmismatched (HLA-haploidentical) related donors. Bone Marrow Transplant 42 : 365-377.

10. Cornelissen JJ, van der Holt B, Petersen EJ, Vindelov L, Russel CA, et al (2003) A randomized multicenter comparison of CD34(+)-selected progenitor cells from blood vs from bone marrow in recipients of HLA-identical allogeneic transplants for hematological malignancies. Exp Hematol 10: 855-864.
11. Klingebiel T, Cornish J, Labopin M, Locatelli F, Darbyshire P, et al. (2010) Results and factors influencing outcome after fully haploidentical hematopoietic stem cell transplantation in children with very high-risk acute lymphoblastic leukemia: impact of center size: an analysis on behalf of the Acute Leukemia and Pediatric Disease Working Parties of the European Blood and Marrow Transplant group. Blood 115: 3437-3446.

12. Regulation (EC) No 1394/2007 of the European Parliament and of the Council (2007) Advanced therapy medicinal products and amending Directive 2001/83/ EC and Regulation (EC) No 726/2004.

13. Hosoda T, Rota M, Kajstura J, Leri A, Anversa P (2011) Role of stem cells in cardiovascular biology. J Thromb Haemost 9: 151-161.

14. Haller MJ, Wasserfall CH, McGrail KM, Cintron M, Brusko TM, et al. (2009) Autologous umbilical cord blood transfusion in very young children with type 1 diabetes. Diabetes Care 32: 2041-2046.

15. Kollar K, Seifried E, Henschler R (2011) Therapeutic potential of intravenously administered human mesenchymal stromal cells. Hämostaseologie 31: 269274

16. Kurtzberg J, Prasad VK, Carter SL, Wagner JE, Baxter-Lowe LA, et al. (2008) Results of the Cord Blood Transplantation Study (COBLT): clinical outcomes of unrelated donor umbilical cord blood transplantation in pediatric patients with hematologic malignancies. Blood 112: 4318-4327.

17. Prasad VK, Mendizabal A, Parikh SH, Szabolcs P, Driscoll TA, et al. (2008) Unrelated donor umbilical cord blood transplantation for inherited metabolic disorders in 159 pediatric patients from a single center: influence of cellula composition of the graft on transplantation outcomes. Blood 112: 2979-2989.

18. Delaney C, Ratajczak MZ, Laughlin MJ (2010) Strategies to enhance umbilical cord blood stem cell engraftment in adult patients. Expert Rev Hematol 3: $273-$ 283.

19. Brown JA, Boussiotis VA (2008) Umbilical Cord Blood Transplantation: Basic Biology and Clinical Challenges to Immune Reconstitution. Clin Immunol 127 286-297.

20. Gutman JA, Turtle CJ, Manley TJ, Heimfeld S, Bernstein ID, et al. (2010) Single-unit dominance after double-unit umbilical cord blood transplantation coincides with a specific CD8+ T-cell response against the nonengrafted unit. Blood 115: 757-765.

21. Yang H, Robinson SN, Lu J, Decker WK, Xing D, et al. (2010) CD3(+) and/ or CD14(+) depletion from cord blood mononuclear cells prior to ex vivo expansion culture improves total nucleated cell and CD34(+) cell yields. Bone Marrow Transplant 45: 1000-1007.

22. Bart T (2010) Cost effectiveness of cord blood versus bone marrow and peripheral blood stem cells. Clinicoecon Outcomes Res 2: 141-147.

23. Fruehauf S, Veldwijk MR, Seeger T, Schubert M, Laufs S, et al. (2009) A combination of granulocyte-colony-stimulating factor (G-CSF) and plerixafor mobilizes more primitive peripheral blood progenitor cells than G-CSF alone: results of a European phase II study. Cytotherapy 11: 992-1001.

24. Chitteti BR, Liu Y, Srour EF (2011) Genomic and proteomic analysis of the impact of mitotic quiescence on the engraftment of human CD34+ cells. PLoS ONE 6: e17498.

25. Zaia JA, Sun JY, Gallez-Hawkins GM, Thao L, Oki A, et al. (2009) The effect of single and combined activating KIR genotypes on CMV infection and immunity after hematopoietic cell transplantation. Biol Blood Marrow Transplant 15: 315 325 .

26. Cooley S, Trachtenberg E, Bergemann TL, Saeteurn K, Klein J, et al. (2009) Donors with group B KIR haplotypes improve relapse-free survival afte unrelated hematopoietic cell transplantation for acute myelogenous leukemia. Blood 113: 726-732.

27. Walter DH, Krankenberg H, Balzer JO, Kalka C, Baumgartner I, Schlüter M Tonn T, Seeger F, Dimmeler S, Lindhoff-Last E, Zeiher AM (2011) Intraarteria administration of bone marrow mononuclear cells in patients with critical limb ischemia: a randomized-start, placebo-controlled pilot trial (PROVASA). Circ Cardiovasc Interv 4: 26-37.

This article was originally published in a special issue, Hematologic Oncology: Diagnosis \& Therapeutics handled by Editor(s). Dr. Ulrich Mahlknecht, Saarland University, Germany 